\title{
Fruit Ripening Development of 'Valencia' Orange Trees Grafted on Different 'Trifoliata' Hybrid Rootstocks
}

\author{
Allan Ricardo Domingues ${ }^{1}$ (1), Ciro Daniel Marques Marcolini ${ }^{2}$, Carlos Henrique da Silva Gonçalves ${ }^{2}$, \\ Leandro Simões Azeredo Gonçalves ${ }^{1}{ }^{1}$, Sergio Ruffo Roberto ${ }^{1, *} \mathbb{1}$ and Eduardo Fermino Carlos ${ }^{2}$ \\ 1 Agricultural Research Center, State University of Londrina, Celso Garcia Cid Road, km 380, P.O. Box 10.011, \\ Londrina ZIP 86057-970, Brazil; allanrdomingues@gmail.com (A.R.D.); leandrosag@uel.br (L.S.A.G.) \\ 2 Development Agronomic Institute of Paraná-IDR-IAPAR, Celso Garcia Cid Road, km 375, \\ Londrina ZIP 95700-00, Brazil; ciromarcolini@emater.pr.gov.br (C.D.M.M.); \\ carloshg@itaipu.gov.br (C.H.d.S.G.); efcarlos@iapar.br (E.F.C.) \\ * Correspondence: sroberto@uel.br; Tel.: +55-43-3371-4774
}

Citation: Domingues, A.R.; Marcolini, C.D.M.; Gonçalves, C.H.d.S. Gonçalves, L.S.A.; Roberto, S.R.; Carlos, E.F. Fruit Ripening Development of 'Valencia' Orange Trees Grafted on Different 'Trifoliata' Hybrid Rootstocks. Horticulturae 2021, 7,3. https://doi.org/10.3390/ horticulturae7010003

Received: 19 November 2020 Accepted: 22 December 2020

Published: 29 December 2020

Publisher's Note: MDPI stays neutral with regard to jurisdictional claims in published maps and institutional affiliations.

Copyright: (C) 2020 by the authors. Licensee MDPI, Basel, Switzerland. This article is an open access article distributed under the terms and conditions of the Creative Commons Attribution (CC BY) license (https: / / creativecommons.org / licenses/by/4.0/).

\begin{abstract}
The development of fruit ripening of 'Valencia' orange trees [Citrus sinensis (L.) Osb.] grafted on the following 'Trifoliata' hybrid rootstocks: 'US-852', IPEACS-256 and IPEACS-264 citrandarins, and F.80-3, 'W-2' citrumelo, and 'Swingle' citrumelo (control), was assessed in three different subtropical locations: Rancho Alegre (RA); São Sebastião da Amoreira (SSA); and São Jerônimo da Serra (SJS), Parana state, Brazil. The climate of the RA and SSA locations was classified as Cfa with hot summers, whereas that of the SJS location was $\mathrm{Cfb}$ with temperate summers, which are located at 380,650, and $835 \mathrm{~m}$ a.s.l., respectively. A completely randomized block design with four replications and four trees per plot was used as a statistical model for each location. The soluble solids (SS) content, titratable acidity (TA), and the maturation index (MI) or ratio (SS/TA) of the juice, as well as the citrus color index (CCI) of fruit skin, were assessed monthly, beginning 200 days after flowering until harvest, totaling seven sampling dates. The data sets of each location were analyzed independently through a two-way analysis of variance (ANOVA) involving rootstocks in a split plot array in time (days) to allow for the assessment of the significance of the main effects, complemented by regression analysis. In general, the ripening of 'Valencia' orange fruits was influenced by the different 'Trifoliata' hybrid rootstocks. At the RA location, trees on IPEACS-256 and' US-852' citrandarins had the highest SS, and on 'US-852' citrandarin had the highest MI, reaching the $\mathrm{MI}_{\mathrm{im}}$ earlier than the other rootstocks. The highest CCI was achieved when trees were on IPEACS-256 citrandarin. At the SSA location, trees on 'US-852', IPEACS-256, and IPEACS-264 citrandarins had the highest SS, but on 'US-852' had the highest MI, reaching the earliest MI $_{\mathrm{im}}$ among the rootstocks. The highest CCI was achieved when trees were on 'US-852' and IPEACS-256 citrandarins. In the SSJ location, there was no significant effect of the rootstocks on and of the variables of 'Valencia' orange fruit. This assessment can be useful in the planning of new orchards producing high-quality fruit with desirable features for the orange juice industry.
\end{abstract}

Keywords: Citrus sinensis (L.) Osb.; rootstocks; maturation index; citrus color index

\section{Introduction}

'Valencia' sweet orange [Citrus sinensis (L.) Osb.] is grown in the most citrus-producing countries and commonly represents the leading commercial variety [1,2]. In Brazil, this species is prominent among producers owing to high fruit yield and quality. Further, this variety has late-maturing fruit, which are intended for both fresh fruit markets as well as industrial processing into juice [3,4]. The production of 'Valencia' oranges for industrial processing in the form of frozen concentrated juice (FCOJ) and not from concentrated juice (NFC) serves as one of the main activities of the citrus industry with a broad economic impact worldwide [5]. However, the production of raw materials must be of high quality to maintain the sector's market competitiveness. The quality attributes of the fruits are 
determined by their physicochemical characteristics, which in turn vary during the ripening period $[6,7]$.

The ripening of citrus fruit passes through different phenological stages, and the final stage is characterized by a reduced growth rate with an increase in soluble solids (SS) content, a decrease in titratable acidity (TA), and changes in skin color [8]. The SS content and TA, along with the relationship between them, also known as the maturation index (MI) or ratio (SS/TA), are considered the main indicators of harvest quality [9-11]. MI represents the balance between the content of sugars and organic acids in fruit, is associated with juice taste, and is widely used by the processing industry as an indicator of maturation and internal quality of fruit [7,12]. MI is considered when adjusting harvest-to-fruit destinations, either for fresh fruit markets or processing, depending on the demand from the importing country. Thus, analyzing these indicators throughout the ripening process allows for the establishment of optimal harvesting time and, consequently, improved quality of fruit for the production sector.

In citrus and other fruit species, including grapes (Vitis spp.) and apples (Malus domestica), grafting is a well-developed technique which combines a scion and a rootstock to form a new tree with a blend of characteristics, and the interaction between the rootstock and scion in a grafted tree is based on various physiological parameters [13-16]. In addition, the ripening of orange fruit is strongly influenced by the climatic conditions of the growing region $[6,8,17]$. The rootstock can manipulate a grafted citrus tree in many ways. It can induce tolerance or resistance to soil-borne stresses and diseases while manipulating horticultural attributes, such as tree size, yield, nutrient uptake, water potential, and fruit quality, including the development of ripening, color of skin and juice, SS and TA contents, and other juice characteristics $[18,19]$. Moreover, selection of an appropriate graft combination should prioritize those that provide better fruit quality to meet the demands of the orange juice industry.

The search for new rootstocks that positively affect the characteristics of sweet oranges has led to the introduction of hybrids of 'Trifoliata' [Poncirus trifoliata (L.) Raf.] with mandarin (Citrus reticulata Blanco) or grapefruit (Citrus paradisi Macf.), also known as citrandarins and citrumelos, respectively. These have been evaluated as alternatives for the diversification of rootstocks in Brazil and several other countries [20-23]. Among the alternatives are 'US-852', 'IPEACS-256', and 'IPEACS-264' citrandarins and 'Swingle' and ‘F.80-3' citrumelos [20,23-29].

When grafted on 'Trifoliata' hybrid rootstocks, orange trees produce high-quality fruit with desirable attributes for the juice industry, such as high SS content and juice yield [20,23,30-33]. 'Swingle' is the best-known citrumelo in Brazil and globally. It is among the main rootstocks used for diversifying orange groves, providing scions with high-quality fruit, increased juice yield, SS content and yield, and reduced scion vigor [21,30].

Analysis of orange fruit ripening development enables the identification of groups of scion/rootstock combinations with different physicochemical characteristics and harvest dates, permitting improved planning of the establishment of new orchards for producing high-quality orange juice [17,34]. Thus, it is possible to establish the optimal harvest point for each scion/rootstock combination within specific regions [35]. Therefore, we aimed to assess the ripening development of 'Valencia' oranges when trees are grafted on different 'Trifoliata' hybrid rootstocks grown in different subtropical locations.

\section{Materials and Methods}

\subsection{Locations and Plant Material}

The fruit ripening development of 'Valencia' orange tree clone IAC [Citrus sinensis (L.) Osb.] grafted on different 'Trifoliata' [Poncirus trifoliata (L.) Raf.] hybrid rootstocks was assessed, and the experiment included the following rootstocks: 'US-852', IPEACS-256, and IPEACS-264 citrandarins [Citrus reticulata Blanco $\times$ P. trifoliata (L.) Raf.]; F.80-3 and 'W-2' citrumelo; 'Swingle' citrumelo (considered as control) [Citrus paradisi Macf. $\times$ P. trifoliata (L.) Raf.]. 
The work was assessed concomitantly in three humid subtropical areas without a dry season in the State of Parana, Brazil, as follows: Rancho Alegre (RA) $\left(23^{\circ} 03^{\prime} 15^{\prime \prime} \mathrm{S}\right.$, $50^{\circ} 55^{\prime} 50^{\prime \prime} \mathrm{W}$, elevation 380 m a.s.l.); São Sebastião da Amoreira (SSA) $\left(23^{\circ} 24^{\prime} 47^{\prime \prime} \mathrm{S}, 50^{\circ} 43^{\prime} 45^{\prime \prime} \mathrm{W}\right.$, elevation $650 \mathrm{~m}$ a.s.1.); and São Jerônimo da Serra (SJS) $\left(23^{\circ} 44^{\prime} 04^{\prime \prime} \mathrm{S}, 50^{\circ} 52^{\prime} 32^{\prime \prime} \mathrm{W}\right.$, elevation $835 \mathrm{~m}$ a.s.l.). The three locations were chosen because they represent different citrus growing conditions in this subtropical region.

According to the Köppen classification, the climate of the RA and SSA locations is Cfa with hot summers, whereas that of the SJS location is Cfb with temperate summers [36]. The higher the elevation of the location, the greater the thermal amplitude, which is the variation of the air temperature between day and night. The average annual rainfall at the RA and SSA locations is $1300 \mathrm{~mm}$, and the average temperatures are 22.1 and $21.1{ }^{\circ} \mathrm{C}$, respectively. At the SJS location, the average rainfall is $1500 \mathrm{~mm}$, and the average temperature is $20.1^{\circ} \mathrm{C}$. The relative humidity is between 75 and $80 \%$, with higher rainfall during spring and summer [37].

The budded trees were transplanted into the trials in mid-summer 2013 at commercial field sites, with a spacing of $6.0 \times 2.5 \mathrm{~m}$ (between-row $\times$ in-row) and were non-irrigated. A completely randomized block design with four replications of each rootstock and four trees per replicate plot was used as a statistical model for each location. In each plot, the two outer trees were considered side borders, and the two inner trees were subjected to evaluations. The rootstock trial plantings were adjacent to a commercial orchard of 'Valencia' orange trees, and the management of the trial blocks was the same as the contiguous commercial blocks.

The 'US-852' citrandarin used in these trials is a cross between the 'Changsha' mandarin and the 'English Large' trifoliate created by Joe Furr at Indio, California, USA in 1965, officially released in 1999 by Kim D. Bowman of the USDA/ARS/HRL, Fort Pierce, FL, USA [25,27]. It was introduced to Brazil in 1982 through deposition into the Active Germplasm Bank (Banco Ativo do Germoplasma-BAG) at the Sylvio Moreira Citriculture Center, Agronomic Institute of Campinas (Centro de Citricultura Sylvio Moreira, Instituto Agronômico de Campinas-CCSM/IAC), Cordeirópolis, SP under access code \#1454.

The IPEACS-256 citrandarin is a cross between the 'Cleopatra' mandarin and the 'English' trifoliata, with no official record of its origin or the breeder responsible for obtaining it. It was first made available by the former Research and Agricultural Experimentation Institute of Central-South Region (Instituto de Pesquisas e Experimentação Agropecuária do Centro-Sul-IPEACS), Itaguaí, RJ, Brazil. It was introduced in 1975 through deposition into the BAG of CCSM/IAC under access code \#1483. The IPEACS-264 citrandarin is a cross between the 'Sunki' mandarin and the 'English' trifoliata, and also does not have any official record of its origin. It was first made available by the former IPEACS and was introduced in 1970 through deposition to the CCSM/IAC BAG under access code \#1628. However, the IPEACS-256 and IPEACS-264 citrandarins were referred to as 'Indio' and 'Riverside', respectively [38].

The F.80-3 citrumelo is a cross, originally performed in 1955 by Mortimer Cohen at the Indian River Field Laboratory, Fort Pierce, FL, USA [39], and was introduced through deposition into the BAG of CCSM/IAC in 1990 under access code \#1460. The 'W-2' citrumelo is another hybrid of USA origin and was introduced into the BAG of CCSM/IAC in 1990 under the access code \#1455.

The 'Swingle' citrumelo is a cross between the 'Duncan' grapefruit and 'Trifoliata', performed in 1907 by Walter T. Swingle of the USDA, Eustis, FL, USA [20]. The acronym, CPB4475, was first used and the fruit was only officially released in 1974 under the name 'Swingle' in honor of its creator [39]. It was introduced into the BAG of CCSM/IAC in 1990 under access code \#401.

All citrandarins and citrumelos evaluated in the present study were introduced into the BAG of CCSM/IAC by the researcher Jorgino Pompeu Jr. The nursery trees of the different scion/rootstock combinations used in the present study were produced by Pratinha Citrus 
Nurseries, a certified nursery of citrus trees located in Paranavaí, PR, and the propagation material was provided by CCSM/IAC, Cordeirópolis, SP.

\subsection{Physicochemical Analysis of Fruits}

The fruit samples were collected during the 2017 and 2018 seasons, and the analyses were performed at the Citrus Laboratory of Cooperativa Integrada Agroindustry processing plant, located at Uraí, PR. The fruit ripening development of 'Valencia' orange trees grafted on each rootstock was assessed monthly by collecting samples of 16 fruits from each plot. Fruit samples were juiced using an FMC citrus juice extractor, and juice quality was analyzed using standard laboratory methods. The evaluations began approximately 200 days after the beginning of flowering when the fruit were approximately $90 \%$ of their final size, which corresponds to phenological stage \#79 according to the $\mathrm{BBCH}$ phenological growth stages and identification keys for citrus trees [40]. The zero time was defined for the first fruit sampling (late summer), extending until fruit harvest (early spring), totaling seven monthly samplings from March to September. The samples were randomly collected from the periphery of the trees between 1.0 and $2.0 \mathrm{~m}$ from the soil, with one fruit collected from each quadrant of each evaluated tree. At the SJS location, only the 'Swingle' and 'W-2' citrumelos were evaluated as the fruit production of trees grafted on the other rootstocks was insufficient for evaluation.

Aiming at assessing the effect of the different rootstocks on ripening development of 'Valencia' orange fruits at each location independently, the samples were submitted to physicochemical analysis, such as the SS contents, TA, and MI (or SS/TA) of the juice, as well the color of fruit skin by means of the citrus color index-CCI.

SS content was determined by direct reading of the juice on a refractometer (model PAL-ALPHA, Atago ${ }^{\circledR}$, Tokyo, Japan) with automatic temperature compensation, and the result was expressed in ${ }^{\circ}$ Brix. The TA was determined by titration of $25 \mathrm{~mL}$ of juice with $0.1 \mathrm{~N} \mathrm{NaOH}$ solution, with the endpoint adjusted to $\mathrm{pH} 8.2$, and the result was expressed as the percentage of citric acid [41]. The MI was calculated as SS/TA. MI = 14 was considered the ideal mean $\left(\mathrm{MI}_{\mathrm{im}}\right)$ for processing 'Valencia' oranges, either for the production of FCOJ or NFC orange juice [42].

The CCI was determined using a digital color reader (model CR10 Plus, KonicaMinolta, Tokyo, Japan) to obtain the variables, $L^{*}, a^{*}$, and $b^{*}$. Readings were performed on the outer equatorial part of the skin of eight fruit per plot. These variables were then used to calculate the CCI using the formula: $\mathrm{CCI}=\left(1000 \times a^{*}\right) /\left(L^{*} \times b^{*}\right)$. The CCI values below -7 represent green with increased intensity and more negative values. Values ranging from -7 to 0 represent shades starting from light green, passing through yellowish-green, and reaching pale yellow, and values between 0 and 7 represent shades ranging from pale yellow to orange. Values above 7 represent orange, which rose in intensity as CCI increased. The time when $\mathrm{CCI}=0$ corresponds to the color of the fruit skins beginning to change from green to pale yellow [43]. Figure 1 illustrates the development of the CCI of fruits of 'Valencia' orange according to different stages of ripening.

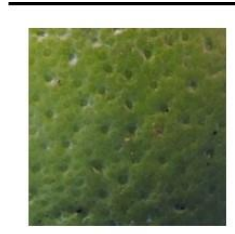

$-8.4$

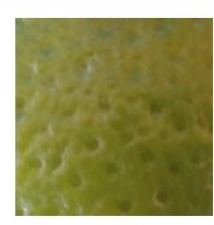

$-3.5$

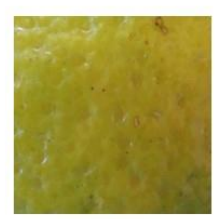

$-0.8$

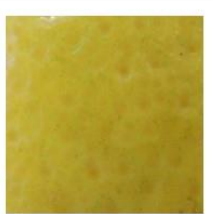

0.7

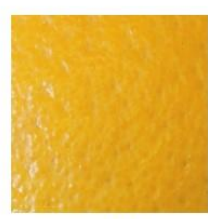

3.9

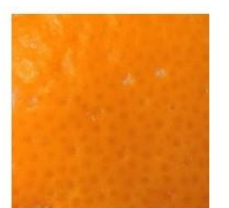

10.6

Figure 1. Representation of the development of the citrus color index (CCI) of 'Valencia' orange fruits when trees are grafted on different 'Trifoliata' hybrid rootstocks in different stages of ripening. 


\subsection{Statistical Analyses}

The data sets of SS, TA, MI, and CCI, obtained from the monthly samplings from each of the three locations, were analyzed independently in a two-way analysis of variance (ANOVA) involving rootstocks in a split plot array in time (days) to allow the assessment of the significance of the main effects. Means were compared by Tukey's honestly significant difference (HSD) test at $p<0.05$. To determine the effect of the 'Trifoliata' hybrid rootstocks on fruit ripening development of 'Valencia' orange at each location, a regression analysis was carried out. The model with the best fit was determined considering the coefficient of determination $\left(R^{2}\right)$, which was adjusted to the number of parameters using the SISVAR software [44] and R [45]. Next, the number of days was predicted so that fruits of 'Valencia' orange trees on each rootstock reached $\mathrm{MI}_{\mathrm{im}}=14$ and $\mathrm{CCI}=0$ at the three locations.

\section{Results and Discussion}

At the RA location, significant differences among the 'Trifoliata' hybrid rootstocks were observed for SS, MI, and CCI of 'Valencia' orange fruit (Table 1). An effect of time (in days) for all variables analyzed was also observed. For SS content, significant differences were observed after 60 days of the beginning of the evaluations, and the rootstocks IPEACS256 and 'US-852' citrandarins had the highest means until the last evaluation (Table 2). A similar pattern was observed for MI, and during the last evaluation, the 'US-852' citrandarin exhibited the highest mean, and the 'Swingle' citrumelo the lowest (Table 2). Regarding the CCI, differences among rootstocks were also observed from the 60th day after the beginning of the evaluations, and on the last day, the IPEACS-256 citrandarin had the highest mean, and the citrumelos had the lowest (Table 2).

At the SSA location, the effect of the different 'Trifoliata' hybrid rootstocks on 'Valencia' orange fruits was observed for SS, MI, and CCI (Table 3). A significant interaction between rootstocks and time in days was only verified for SS content. For this juice characteristic, the differences were observed after 90 days from the beginning of the evaluations, and for the last one, the highest means were noted when the trees were grafted on 'US-852', IPEACS-256, and IPEACS-264 citrandarins (Table 4).

Regarding MI, the 'US-852' citrandarin had the highest mean among the evaluations (Table 4). The effect of the rootstocks on the CCI of orange skins was observed during harvest, where the 'US-852' and IPEACS-256 citrandarins resulted in the highest means, and the 'Swingle' citrumelo the lowest (Table 4).

At the SSJ location, there was no significant effects of rootstocks on 'Valencia' orange fruits for all variables evaluated (Tables 5 and 6). However, the effect of the time in days was significant, but it must be noted that, at this location, only the ' $\mathrm{W}-2$ ' and 'Swingle' citrumelos were assessed as the fruit production of trees grafted on the other 'Trifoliata' hybrid rootstocks was inadequate for evaluation.

Table 1. Analysis of variance and mean squares of soluble solids (SS), titratable acidity (TA), maturation index (MI) or ratio, and citrus color index (CCI) over time of 'Valencia' orange fruits when trees are grafted on different 'Trifoliata' hybrid rootstocks at Rancho Alegre.

\begin{tabular}{|c|c|c|c|c|c|}
\hline Sources of Variance & $\mathrm{Df}^{\mathrm{z}}$ & SS & TA & MI & $\mathrm{CCI}^{\mathrm{y}}$ \\
\hline Blocks & 3 & 0.2766 & 0.0343 & 1.64 & 3.47 \\
\hline Rootstocks (R) & 5 & $5.11^{* * x}$ & 0.0114 & $4.86^{* *}$ & $8.82 * *$ \\
\hline Error A & 15 & 0.364 & 0.032 & 0.95 & 1.28 \\
\hline Days (D) & 6 & $45.43^{* *}$ & $7.69 * *$ & $415.07^{* *}$ & $925.67^{* *}$ \\
\hline $\mathrm{R} \times \mathrm{D}$ & 30 & $0.3587^{* *}$ & 0.0409 & $0.72 * *$ & $2.81 * *$ \\
\hline Error B & 108 & 0.1519 & 0.0353 & 0.57 & 1.23 \\
\hline $\operatorname{CV} 1(\%)^{\mathrm{w}}$ & & 6.4 & 12.6 & 11.1 & 4.3 \\
\hline CV $2(\%)$ & & 4.1 & 13.2 & 8.6 & 4.2 \\
\hline
\end{tabular}

${ }^{\mathrm{z}}$ df: degrees of freedom. ${ }^{\mathrm{y}}$ Original data transformed into $\mathrm{x}+30 .{ }^{\mathrm{x} * *}$ : significant $(p<0.05) .{ }^{\mathrm{w}} \mathrm{CV}=$ coefficient of variation. 
Considering the regression analysis of the fruit ripening development of 'Valencia' orange grafted on different Trifoliata hybrid rootstocks, the SS content exhibited an increasing pattern, adjusting to the quadratic model for all three locations (Figures 2A, $3 \mathrm{~A}$ and $4 \mathrm{~A}$ ). The TA development of fruit was better adjusted by the linear regression model with decreasing values for all locations and all evaluated rootstocks. The 'Trifoliata' hybrid rootstocks induced very similar TA values throughout the ripening period (Figures $2 \mathrm{~B}, 3 \mathrm{~B}$ and $4 \mathrm{~B}$ ).

The MI of the 'Valencia' fruits of the three locations all demonstrated increasing development, and this characteristic of maturation was better adjusted to the linear model (Figures 5A, 6A and 7A). Moreover, the CCI of 'Valencia' orange fruits at all three locations assessed also increased over time and was better adjusted to the quadratic model (Figures 5B, 6B and 7B).

At the RA location, a subtropical region with a hot summer and at low elevation (380 $\mathrm{m}$ a.s.l.), the fruits of trees grafted on 'US-852' citrandarin reached the $\mathrm{MI}_{\mathrm{im}}$ earlier than the other 'Trifoliata' hybrid rootstocks, in an estimated period of 158 days after the beginning of the evaluations, followed by IPEACS-256 citrandarin, F.80-3 citrumelo, IPEACS-264 citrandarin, 'W-2' and 'Swingle' citrumelos (162, 173, 182, 182, and 187 days, respectively) (Figure 5A). The earliest estimated period that fruits changed skin color from green to pale yellow, corresponding to a $\mathrm{CCI}=0$, was also observed when the orange trees were grafted on 'US-852' citrandarin, with an estimated period of 107 days after the beginning of the evaluations, followed by IPEACS-256 and IPEACS-264 citrandarins, and F.80-3, 'W-2', and 'Swingle' citrumelos (110, 124, 135, 136, and 141 days, respectively) (Figure 5B). At this location, considering the $\mathrm{MI}_{\mathrm{im}}$, the main characteristic for fruit processing, the evaluated rootstocks strongly influenced the ripening of 'Valencia' oranges, with a maximum variation of 29 days from the earliest ('US-852' citrandarin) to the latest ('Swingle' citrumelo) ripening.

Table 2. Soluble solids, maturation index or ratio, and citrus color index of 'Valencia' orange fruits when trees are grafted on different 'Trifoliata' hybrid rootstocks at Rancho Alegre at different times after the phenological stage BBCH \#79.

\begin{tabular}{|c|c|c|c|c|c|c|c|}
\hline \multirow{3}{*}{ Rootstocks } & \multicolumn{7}{|c|}{ Soluble Solids-SS ( ${ }^{\circ}$ Brix) } \\
\hline & \multicolumn{7}{|c|}{ Days after the Phenological Stage ВВСН \#79 z } \\
\hline & 0 & 30 & 60 & 90 & 120 & 150 & 180 \\
\hline ‘US-852’ citrandarin & $6.9 \mathrm{~b}^{\mathrm{y}}$ & $8.1 \mathrm{a}$ & $9.1 \mathrm{ab}$ & $10.1 \mathrm{ab}$ & $10.8 \mathrm{ab}$ & $11.3 \mathrm{ab}$ & $10.7 \mathrm{ab}$ \\
\hline IPEACS-256 citrandarin & $7.9 \mathrm{a}$ & $8.1 \mathrm{a}$ & $9.9 \mathrm{a}$ & $10.7 \mathrm{a}$ & $11.5 \mathrm{a}$ & $11.8 \mathrm{a}$ & $11.4 \mathrm{a}$ \\
\hline IPEACS-264 citrandarin & $6.9 \mathrm{~b}$ & $8.0 \mathrm{a}$ & $8.9 b$ & $9.8 b$ & $10.3 b$ & $10.5 b c$ & $9.6 c$ \\
\hline F.80-3 citrumelo & $7.2 \mathrm{ab}$ & $8.1 \mathrm{a}$ & $8.9 b$ & $9.6 \mathrm{~b}$ & $10.4 b$ & $10.2 \mathrm{c}$ & $9.3 c$ \\
\hline ‘W-2' citrumelo & $7.1 \mathrm{ab}$ & $7.8 \mathrm{a}$ & $8.9 b$ & $9.3 b$ & $10.0 \mathrm{~b}$ & $10.3 c$ & $9.6 c$ \\
\hline \multirow[t]{3}{*}{ 'Swingle' citrumelo } & $6.7 \mathrm{~b}$ & $8.1 \mathrm{a}$ & $9.2 \mathrm{~b}$ & $10.0 \mathrm{ab}$ & $10.6 \mathrm{ab}$ & $10.7 \mathrm{bc}$ & $10.1 b c$ \\
\hline & \multicolumn{7}{|c|}{ Maturation index-MI or ratio } \\
\hline & 0 & 30 & 60 & 90 & 120 & 150 & 180 \\
\hline ‘US-852’ citrandarin & $2.8 \mathrm{a}$ & $4.9 \mathrm{a}$ & $7.1 \mathrm{a}$ & $9.2 \mathrm{a}$ & $12.9 \mathrm{a}$ & $13.3 \mathrm{ab}$ & $14.8 \mathrm{a}$ \\
\hline IPEACS-256 citrandarin & $3.1 \mathrm{a}$ & $4.7 \mathrm{a}$ & $6.7 \mathrm{a}$ & $8.9 \mathrm{ab}$ & $12.6 \mathrm{ab}$ & $13.3 \mathrm{a}$ & $14.4 \mathrm{ab}$ \\
\hline IPEACS-264 citrandarin & $2.9 \mathrm{a}$ & $5.1 \mathrm{a}$ & $5.8 \mathrm{a}$ & $7.3 b$ & $11.9 \mathrm{ab}$ & $11.7 \mathrm{~b}$ & $13.7 \mathrm{ab}$ \\
\hline F.80-3 citrumelo & $3.4 \mathrm{a}$ & $4.9 \mathrm{a}$ & $6.6 a$ & $8.8 \mathrm{ab}$ & $12.4 \mathrm{ab}$ & $12.4 \mathrm{ab}$ & $13.7 \mathrm{ab}$ \\
\hline ‘W-2' citrumelo & $3.4 \mathrm{a}$ & $4.7 \mathrm{a}$ & $6.8 \mathrm{a}$ & $7.5 \mathrm{ab}$ & $11.0 \mathrm{~b}$ & $12.3 \mathrm{ab}$ & $13.8 \mathrm{ab}$ \\
\hline \multirow[t]{3}{*}{ 'Swingle' citrumelo } & $3.1 \mathrm{a}$ & $5.0 \mathrm{a}$ & $6.2 \mathrm{a}$ & $7.9 \mathrm{ab}$ & $11.2 b$ & $11.9 \mathrm{ab}$ & $13.1 b$ \\
\hline & \multicolumn{7}{|c|}{ Citrus color index-CCI } \\
\hline & 0 & 30 & 60 & 90 & 120 & 150 & 180 \\
\hline ‘US-852' citrandarin & $-11.8 \mathrm{a}$ & $-11.3 a$ & $-5.2 \mathrm{ab}$ & $-0.8 \mathrm{ab}$ & $1.8 \mathrm{a}$ & $3.2 \mathrm{a}$ & $3.4 \mathrm{ab}$ \\
\hline IPEACS-256 citrandarin & $-12.5 \mathrm{a}$ & $-12.5 \mathrm{a}$ & $-3.9 a$ & $0.4 \mathrm{a}$ & $0.8 \mathrm{ab}$ & $3.8 \mathrm{a}$ & $4.0 \mathrm{a}$ \\
\hline IPEACS-264 citrandarin & $-12.5 \mathrm{a}$ & $-10.7 \mathrm{a}$ & $-6.2 b$ & $-1.3 \mathrm{ab}$ & $0.1 \mathrm{ab}$ & $1.9 \mathrm{ab}$ & $3.6 \mathrm{ab}$ \\
\hline F.80-3 citrumelo & $-10.7 \mathrm{a}$ & $-10.9 a$ & $-4.5 \mathrm{ab}$ & $-1.2 \mathrm{ab}$ & $-0.4 \mathrm{ab}$ & $1.0 \mathrm{~b}$ & $1.1 \mathrm{c}$ \\
\hline 'W-2' citrumelo & $-12.2 \mathrm{a}$ & $-11.0 \mathrm{a}$ & $-6.5 b$ & $-2.2 b$ & $-0.7 \mathrm{~b}$ & $2.1 \mathrm{ab}$ & $2.3 b c$ \\
\hline 'Swingle' citrumelo & $-12.5 \mathrm{a}$ & $17.5 \mathrm{a}$ & $-5.8 \mathrm{ab}$ & $-2.2 b$ & $-0.1 \mathrm{ab}$ & $1.6 \mathrm{ab}$ & $1.7 \mathrm{bc}$ \\
\hline
\end{tabular}

${ }^{\mathrm{z}}$ Approximately 200 days after flowering (Meier, 2001). ${ }^{\mathrm{y}}$ Means with the same letter are not significantly different from each other by Tukey's honestly significant difference test at $p<0.05$. 
Table 3. Analysis of variance and mean squares of soluble solids (SS), titratable acidity (TA), maturation index (MI) or ratio (SS/TA), and citrus color index (CCI) over time of 'Valencia' orange fruits when trees are grafted on different 'Trifoliata' hybrid rootstocks at São Sebastião da Amoreira.

\begin{tabular}{|c|c|c|c|c|c|}
\hline Sources of Variance & $\mathrm{df}^{\mathrm{z}}$ & SS & TA & MI & CCI ${ }^{y}$ \\
\hline Blocks & 3 & 0.2887 & 0.0343 & 1.28 & 0.20 \\
\hline Rootstocks (R) & 5 & $2.7578 * * x$ & 0.01114 & $1.77^{* *}$ & $14.20 * *$ \\
\hline Error A & 15 & 0.3239 & 0.032 & 0.84 & 2.11 \\
\hline Days (D) & 6 & $42.37^{* *}$ & $7.69^{* *}$ & $345.07 * *$ & $948.43^{* *}$ \\
\hline $\mathrm{R} \times \mathrm{D}$ & 30 & $0.3597^{* *}$ & 0.0409 & 0.94 & 1.72 \\
\hline Error B & 108 & 0.2270 & 0.0353 & 0.74 & 1.96 \\
\hline $\operatorname{CV} 1(\%)^{\mathrm{w}}$ & & 6.0 & 12.6 & 11.4 & 5.2 \\
\hline CV $2(\%)$ & & 5.0 & 13.2 & 10.7 & 5.0 \\
\hline
\end{tabular}

${ }^{\mathrm{z}}$ df: degrees of freedom. ${ }^{\mathrm{y}}$ Original data transformed into $\mathrm{x}+30 .{ }^{\mathrm{x} * *}$ : significant $(p<0.05) .{ }^{\mathrm{w}} \mathrm{CV}=$ coefficient of variation.

At the SSA location, a subtropical region with a hot summer and at an intermediate elevation (650 $\mathrm{m}$ a.s.l.), the $\mathrm{MI}_{\mathrm{im}}$ of 'Valencia' fruits was also reached earlier when grafted on 'US-852' citrandarin, with an estimated period of 177 days after the beginning of the evaluations (Figure 6A), followed by 'Swingle' and F.80-3 citrumelos, IPEACS-264 and IPEACS-256 citrandarins, and 'W-2' citrumelo (191, 192, 194, 194, and 202 days, respectively) (Figure 6A). The fruits of 'Valencia' orange trees grafted on the 'Trifoliata' hybrid rootstocks reached CCI $=0$ in a smaller range, from 85 to 93 days (IPEACS-256 and 'US-852', respectively), except for the 'Swingle' citrumelo, which reached this index at 105 days after the beginning of the evaluations (Figure 6B).

At this location, considering the $\mathrm{MI}_{\mathrm{im}}$, the rootstocks also influenced the development of ripening of 'Valencia' orange fruit, with a variation of 25 days from the earliest ('US-852' citrandarin) to the latest ('W-2' citrumelo) ripening.

At the SJS location, a subtropical region with temperate summers and at high elevations (835 $\mathrm{m}$ a.s.l.), the orange fruit did not reach the $\mathrm{MI}_{\mathrm{im}}$ for processing until the last evaluation. Nevertheless, according to the regression analysis, both 'Swingle' and 'W-2' citrumelos expressed a similar late ripening behavior, and the $\mathrm{MI}_{\mathrm{im}}$ was estimated to be reached at 254 days after the beginning of the evaluations (Figure 7A). On the other hand, under the specific weather conditions of this location, with temperate summer and wide temperature range, with warm days and mild nights, both 'Swingle' and 'W-2' citrumelos induced very early pale-yellow skin color $(\mathrm{CCI}=0)$ of 'Valencia' orange fruits at 67 days after the beginning of the evaluations (Figure 7B).

Although external and internal ripening of orange fruits in general coincide, skin and pulp behave in many respects as separate organs and thus can be considered to undergo different physiological processes. Mature citrus pulp contains a very high percentage of water (85-90\%) and many different constituents, including carbohydrates; organic acids; amino acids; vitamin C; minerals; and small quantities of lipids, proteins, and secondary metabolites, such as carotenoids, flavonoids, and volatiles [46].

SS comprises $10-20 \%$ of the fresh weight of the fruit and consists mainly of carbohydrates $(70-80 \%)$ and relatively minor quantities of organic acids, proteins, lipids, and minerals [46]. The accumulation of SS content during the ripening period occurs in growth stage III of sweet oranges, also known as the stage of cell expansion, and it is characterized by a rapid increase in fruit size and SS content, lasting up to 6 months according to the region and growing conditions [8]. The rootstock plays an important role in fruit ripening because it can speed up or delay citrus tree development. In this work, it was shown that the 'US-852' and IPEACS-256 citrandarins anticipated ripening of fruits. In addition, in subtropical regions with hot summers and at low elevations, the duration of stage III can be anticipated to be 3 to 4 months, whereas in subtropical regions with temperate summers, this stage tends to be prolonged, extending up to 10 months. At the end of stage III, fruits tend to accumulate considerable SS content, which is determined by the climatic conditions of the growing regions, particularly water availability. 
Table 4. Soluble solids, maturation index or ratio, and citrus color index of 'Valencia' orange fruits when trees are grafted on different 'Trifoliata' hybrid rootstocks at São Sebastião da Amoreira at different times after the phenological stage BBCH \#79.

\begin{tabular}{|c|c|c|c|c|c|c|c|}
\hline \multirow{3}{*}{ Rootstocks } & \multicolumn{7}{|c|}{ Soluble Solids-SS $\left({ }^{\circ}\right.$ Brix) } \\
\hline & \multicolumn{7}{|c|}{ Days after the Phenological Stage ВВСН \#79 z } \\
\hline & 0 & 30 & 60 & 90 & 120 & 150 & 180 \\
\hline 'US-852' citrandarin & $7.1 \mathrm{a}^{\mathrm{y}}$ & $8.0 \mathrm{a}$ & $9.7 \mathrm{a}$ & $10.4 \mathrm{ab}$ & $10.9 a$ & $10.9 \mathrm{ab}$ & $10.3 a$ \\
\hline IPEACS-256 citrandarin & $7.5 \mathrm{a}$ & $8.4 \mathrm{a}$ & $10.0 \mathrm{a}$ & $10.7 \mathrm{a}$ & $10.9 \mathrm{a}$ & $11.1 \mathrm{ab}$ & $10.6 \mathrm{a}$ \\
\hline IPEACS-264 citrandarin & $7.1 \mathrm{a}$ & $8.2 \mathrm{a}$ & $9.1 \mathrm{a}$ & $10.3 \mathrm{ab}$ & $10.5 \mathrm{a}$ & $10.1 b$ & $10.3 a$ \\
\hline F.80-3 citrumelo & $7.4 \mathrm{a}$ & $8.0 \mathrm{a}$ & $9.4 \mathrm{a}$ & $9.9 \mathrm{ab}$ & $10.3 a$ & $10.3 b$ & $9.3 \mathrm{bc}$ \\
\hline 'W-2' citrumelo & $6.8 \mathrm{a}$ & $7.8 \mathrm{a}$ & $9.4 \mathrm{a}$ & $9.6 \mathrm{~b}$ & $10.2 \mathrm{a}$ & $10.6 \mathrm{ab}$ & $8.7 \mathrm{c}$ \\
\hline \multirow[t]{3}{*}{ 'Swingle' citrumelo } & $7.2 \mathrm{a}$ & $8.2 \mathrm{a}$ & $9.6 a$ & $10.3 \mathrm{ab}$ & $10.8 \mathrm{a}$ & $11.3 \mathrm{a}$ & $9.5 \mathrm{bc}$ \\
\hline & \multicolumn{7}{|c|}{ Maturation index-MI or ratio } \\
\hline & 0 & 30 & 60 & 90 & 120 & 150 & 180 \\
\hline ‘US-852’ citrandarin & $2.7 \mathrm{a}$ & $5.2 \mathrm{a}$ & $6.5 \mathrm{a}$ & $7.9 \mathrm{a}$ & $10.5 \mathrm{a}$ & $12.6 a$ & $14.9 \mathrm{a}$ \\
\hline IPEACS-256 citrandarin & $3.5 \mathrm{a}$ & $4.9 \mathrm{a}$ & $5.4 \mathrm{~b}$ & $7.8 \mathrm{a}$ & $11.1 \mathrm{a}$ & $11.2 \mathrm{~b}$ & $13.0 \mathrm{~b}$ \\
\hline IPEACS-264 citrandarin & $3.1 \mathrm{a}$ & $4.4 \mathrm{a}$ & $5.3 b$ & $8.0 \mathrm{a}$ & $10.7 \mathrm{a}$ & $11.8 \mathrm{~b}$ & $12.5 b$ \\
\hline F.80-3 citrumelo & $3.1 \mathrm{a}$ & $4.5 \mathrm{a}$ & $5.5 b$ & $8.0 \mathrm{a}$ & $9.4 \mathrm{a}$ & $11.1 \mathrm{~b}$ & $13.2 \mathrm{~b}$ \\
\hline 'W-2' citrumelo & $3.0 \mathrm{a}$ & $4.4 \mathrm{a}$ & $5.2 b$ & 7.1a & $10.0 \mathrm{a}$ & $11.5 b$ & $12.4 \mathrm{~b}$ \\
\hline \multirow[t]{3}{*}{ 'Swingle' citrumelo } & $3.0 \mathrm{a}$ & $4.7 \mathrm{a}$ & $5.3 b$ & $7.6 \mathrm{a}$ & $10.9 \mathrm{a}$ & $10.8 \mathrm{~b}$ & $12.9 \mathrm{~b}$ \\
\hline & \multicolumn{7}{|c|}{ Citrus color index-CCI } \\
\hline & 0 & 30 & 60 & 90 & 120 & 150 & 180 \\
\hline ‘US-852' citrandarin & $-12.0 \mathrm{a}$ & $11.4 \mathrm{a}$ & $-3.0 \mathrm{ab}$ & $0.7 \mathrm{a}$ & $2.3 \mathrm{a}$ & $3.7 \mathrm{a}$ & $4.6 a$ \\
\hline IPEACS-256 citrandarin & $-9.8 \mathrm{a}$ & $-9.8 \mathrm{a}$ & $-1.2 \mathrm{a}$ & $0.9 \mathrm{a}$ & $2.8 \mathrm{a}$ & $4.0 \mathrm{a}$ & $4.4 \mathrm{a}$ \\
\hline IPEACS-264 citrandarin & $-11.2 \mathrm{a}$ & $-10.8 \mathrm{a}$ & $-1.4 \mathrm{a}$ & $1.5 \mathrm{a}$ & $2.0 \mathrm{a}$ & $3.2 \mathrm{a}$ & $4.0 \mathrm{ab}$ \\
\hline F.80-3 citrumelo & $-10.7 \mathrm{a}$ & $-10.5 \mathrm{a}$ & $-1.6 a$ & $0.8 \mathrm{a}$ & $1.8 \mathrm{a}$ & $3.1 \mathrm{a}$ & $4.1 \mathrm{ab}$ \\
\hline 'W-2' citrumelo & $-10.9 \mathrm{a}$ & $-9.1 \mathrm{a}$ & $-2.2 \mathrm{a}$ & $0.1 \mathrm{a}$ & $1.3 \mathrm{a}$ & $2.7 \mathrm{a}$ & $3.4 b c$ \\
\hline 'Swingle' citrumelo & $-12.0 \mathrm{a}$ & $-10.9 \mathrm{a}$ & $-5.5 b$ & $-0.2 \mathrm{a}$ & $1.0 \mathrm{a}$ & $1.8 \mathrm{a}$ & $2.2 \mathrm{c}$ \\
\hline
\end{tabular}

${ }^{\mathrm{z}}$ Approximately 200 days after flowering (Meier, 2001). ${ }^{\mathrm{y}}$ Means with the same letter are not significantly different from each other by Tukey's honestly significant difference test at $p<0.05$.

Table 5. Analysis of variance and mean squares of soluble solids (SS), titratable acidity (TA), maturation index (MI) or ratio (SS/TA), and citrus color index (CCI) over time of 'Valencia' orange fruits when trees are grafted on different 'Trifoliata' hybrid rootstocks at São Jerônimo da Serra.

\begin{tabular}{|c|c|c|c|c|c|}
\hline Sources of Variance & $\mathbf{d f}^{\mathrm{z}}$ & SS & TA & MI & $\mathrm{CCI}^{\mathrm{y}}$ \\
\hline Blocks & 3 & 0.2196 & 0.1178 & 1.1933 & 2.70 \\
\hline Rootstocks (R) & 1 & 0.0460 & 0.0240 & 0.3600 & 2.89 \\
\hline Error A & 3 & 0.213 & 0.0393 & 0.4400 & 3.01 \\
\hline Days (D) & 6 & $19.32 * * x$ & $2.0653 * *$ & $67.49 * *$ & $284.25^{* *}$ \\
\hline $\mathrm{R} \times \mathrm{D}$ & 6 & 0.405 & 0.1057 & 0.35 & 1.63 \\
\hline Error B & 36 & 0.3193 & 0.0651 & 0.76 & 2.38 \\
\hline CV $1(\%)^{w}$ & & 4.6 & 11.9 & 9.8 & 8.9 \\
\hline CV $2(\%)$ & & 5.7 & 15.3 & 12.8 & 7.9 \\
\hline
\end{tabular}

${ }^{\mathrm{z}}$ df: degrees of freedom. ${ }^{\mathrm{y}}$ Original data transformed into $\mathrm{x}+30 .{ }^{\mathrm{x} * *}$ : significant $(p<0.05) .{ }^{\mathrm{w}} \mathrm{CV}=$ coefficient of variation. 
Table 6. Soluble solids, maturation index or ratio, and citrus color index of 'Valencia' orange fruits when trees are grafted on different 'Trifoliata' hybrid rootstocks at São Jerônimo da Serra-SJS location at different times after the phenological stage BBCH \#79.

\begin{tabular}{|c|c|c|c|c|c|c|c|}
\hline \multirow{3}{*}{ Rootstocks } & \multicolumn{7}{|c|}{ Soluble Solids-SS ( ${ }^{\circ}$ Brix) } \\
\hline & \multicolumn{7}{|c|}{ Days after the Phenological Stage ВВСН \#79 z } \\
\hline & $\mathbf{0}$ & 30 & 60 & 90 & 120 & 150 & 180 \\
\hline ‘W-2' citrumelo & $7.5 \mathrm{a}^{\mathrm{y}}$ & $7.8 \mathrm{a}$ & $9.7 \mathrm{a}$ & $10.4 \mathrm{a}$ & $11.2 \mathrm{a}$ & $11.8 \mathrm{a}$ & $10.9 \mathrm{a}$ \\
\hline \multirow[t]{3}{*}{ 'Swingle' citrumelo } & $7.7 \mathrm{a}$ & $8.0 \mathrm{a}$ & $10.0 \mathrm{a}$ & $10.7 \mathrm{a}$ & $11.6 \mathrm{a}$ & $11.1 \mathrm{a}$ & $10.4 \mathrm{a}$ \\
\hline & \multicolumn{7}{|c|}{ Maturation index-MI or ratio } \\
\hline & 0 & 30 & 60 & 90 & 120 & 150 & 180 \\
\hline 'W-2' citrumelo & $3.7 \mathrm{a}$ & $3.6 \mathrm{a}$ & $5.0 \mathrm{a}$ & $6.0 \mathrm{a}$ & $8.4 \mathrm{a}$ & $9.6 \mathrm{a}$ & $10.6 \mathrm{a}$ \\
\hline \multirow[t]{3}{*}{ 'Swingle' citrumelo } & $3.4 \mathrm{a}$ & $3.7 \mathrm{a}$ & $4.9 \mathrm{a}$ & $7.0 \mathrm{a}$ & $8.7 \mathrm{a}$ & $9.8 \mathrm{a}$ & $10.7 \mathrm{a}$ \\
\hline & \multicolumn{7}{|c|}{ Citrus color index-CCI } \\
\hline & 0 & 30 & 60 & 90 & 120 & 150 & 180 \\
\hline 'W-2' citrumelo & $-10.4 \mathrm{a}$ & $-9.4 a$ & $-0.4 a$ & $3.4 \mathrm{a}$ & $3.5 a$ & $4.0 \mathrm{a}$ & $4.1 \mathrm{a}$ \\
\hline 'Swingle' citrumelo & $-10.1 \mathrm{a}$ & $-8.7 \mathrm{a}$ & $-0.8 \mathrm{a}$ & $2.4 \mathrm{a}$ & $3.4 a$ & $3.8 \mathrm{a}$ & $4.0 \mathrm{a}$ \\
\hline
\end{tabular}

${ }^{\mathrm{z}}$ Approximately 200 days after flowering (Meier, 2001). ${ }^{\mathrm{y}}$ Means with the same letter are not significantly different from each other by Tukey's honestly significant difference test at $p<0.05$.

It is known that increasing rainfall during stage III may lead to a decrease in SS content by diluting the juice in response to excessive water absorption by trees $[47,48]$. Therefore, the decrease in the SS content of 'Valencia' orange fruits grafted on different rootstocks after reaching the maximum content, which is indicated by quadratic behavior, may have occurred because of the higher rainfall season during the period of SS accumulation in the three locations evaluated. This is a recurrent situation in the ripening of late orange varieties, such as 'Valencia', grown in subtropical regions, where considerable rainfall periods usually coincide with lower concentrations of these sugars.

Generally, fruits of 'Valencia' orange grown at the SJS location, with temperate summers, exhibited a slow decrease in TA during the maturation period. Some authors have reported that fruits grown in regions with hot summers tend to exhibit a rapid decrease in acidity compared with regions with temperate summers owing to the increased respiration rate $[9,12,48,49]$.

Considering the $\mathrm{MI}_{\mathrm{im}}$, the fruits of 'Valencia' orange trees grafted on different 'Trifoliata' hybrid rootstocks grown at the RA location presented early ripeness, with an estimated time to reach this phase from 158 to 187 days after the beginning of the evaluations when grafted on 'US-852' citrandarin and 'Swingle' citrumelo, respectively (Figure 2A). The same trend was observed for both rootstocks when the 'Valencia' orange trees were grown at the SSA location, but the estimated periods that these two rootstocks took to reach this phase were 177 and 191 days, respectively (Figure 2B). According to the regression model adjusted for the SJS location, late ripeness of fruits was observed, as the estimated time to reach the $\mathrm{MI}_{\mathrm{im}}$ ranged from 246 and 261 days after the beginning of the evaluations for 'Swingle' and ' $\mathrm{W}-2$ ' citrumelos, respectively (Figure 4B).

Rootstocks have been demonstrated to change the ripening development of 'Folha Murcha' sweet orange [C. sinensis (L.) Osb.] by inducing different fruit harvest dates, and this difference may range from 8 to 28 days [17]. These authors also found that fruits grown in regions with higher temperatures reached full ripeness up to 92 days earlier. Under subtropical conditions with hot summers, orange fruits ripen and become marketable in a shorter period of time, whereas in milder climates, ripening takes longer $[8,12]$. Thus, this behavior corresponds to the 'Valencia' orange grown at the RA location, with early ripeness. Moreover, the rootstocks induced different harvest dates in 'Valencia' oranges, with emphasis on 'US-852' citrandarin grown in the RA and SSA locations. 


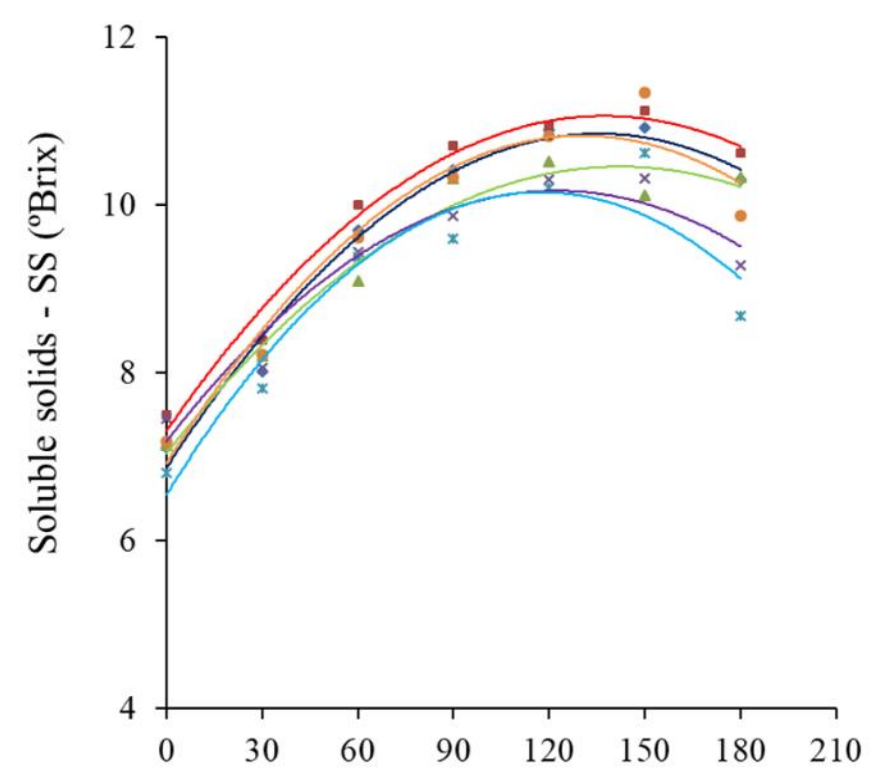

$$
\begin{aligned}
& \text { - 'US-852' citrandarin } \\
& \mathrm{y}=-0.0002 \mathrm{x}^{2}+0.0525 \mathrm{x}+6.751 R^{2}=0.99 \\
& \text { - IPEACS-256 citrandarin } \\
& \mathrm{y}=-0.0001 \mathrm{x}^{2}+0.0483 \mathrm{x}+7.449 R^{2}=0.95 \\
& \triangle \text { IPEACS-264 citrandarin } \\
& \mathrm{y}=-0.0002 \mathrm{x}^{2}+0.0505 \mathrm{x}+6.762 R^{2}=0.97 \\
& \times \text { F. } 80 \text {-3 citrumelo } \\
& \mathrm{y}=-0.0002 \mathrm{x}^{2}+0.0456 \mathrm{x}+7.046 R^{2}=0.94 \\
& \text { x 'W-2' citrumelo } \\
& \mathrm{y}=-0.0001 \mathrm{x}^{2}+0.0405 \mathrm{x}+6.972 R^{2}=0.96 \\
& \text { - 'Swingle' citrumelo } \\
& \mathrm{y}=-0.0002 \mathrm{x}^{2}+0.0564 \mathrm{x}+6.610 R^{2}=0.99
\end{aligned}
$$

Days after $\mathrm{BBCH} \# 79$ phenological stage

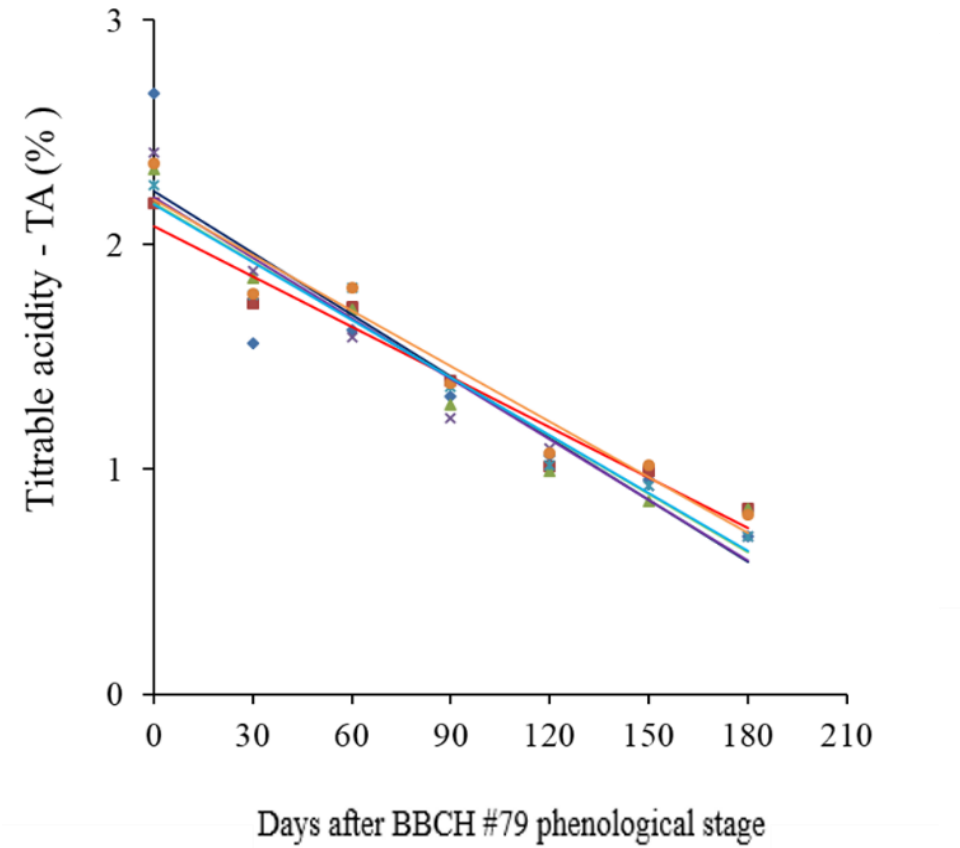

$$
\begin{aligned}
& \text { - 'US-852' citrandarin } \\
& \mathrm{y}=-0.0087 \mathrm{x}+2.06 \quad R^{2}=0.83 \\
& \text { - IPEACS-256 citrandarin } \\
& \mathrm{y}=-0.0089 \mathrm{x}+2.17 \quad R^{2}=0.86 \\
& \triangle \text { IPEACS-264 citrandarin } \\
& \mathrm{y}=-0.0084 \mathrm{x}+2.09 \quad R^{2}=0.88 \\
& \times \text { F.80-3 citrumelo } \\
& \mathrm{y}=-0.0079 \mathrm{x}+1.94 \quad R^{2}=0.93 \\
& \times \text { 'W-2' citrumelo } \\
& \mathrm{y}=-0.0079 \mathrm{x}+1.99 \quad R^{2}=0.96 \\
& \text { - 'Swingle' citrumelo } \\
& \mathrm{y}=-0.0075 \mathrm{x}+1.99 \quad R^{2}=0.93
\end{aligned}
$$

Figure 2. Development of 'Valencia' orange fruit ripening when trees are grafted on different 'Trifoliata' hybrid rootstocks at Rancho Alegre. (A): soluble solids (SS as ${ }^{\circ}$ Brix); (B): titratable acidity (TA as \%). Phenological stage BBCH \#79 (Meier, 2001), approximately to 200 days after flowering. 


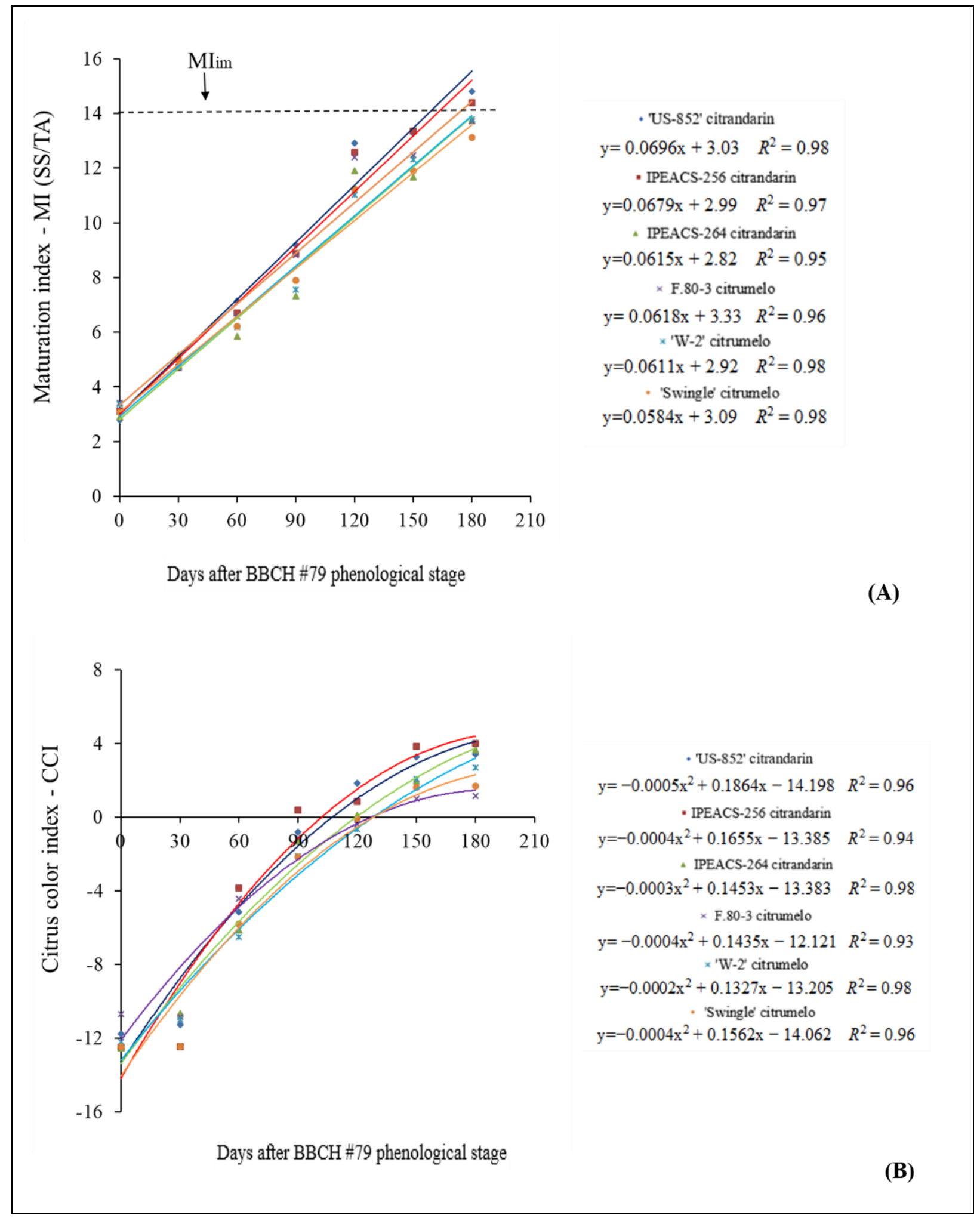

Figure 3. Development of 'Valencia' orange fruit ripening when trees are grafted on different 'Trifoliata' hybrid rootstocks at Rancho Alegre. (A): maturation index (Mi) or ratio (SS/TA); (B): citrus color index (CCI). $\mathrm{MI}_{\mathrm{im}}=$ ideal mean maturation index $=14$. Phenological stage BBCH \#79 (Meier, 2001), approximately to 200 days after flowering. 


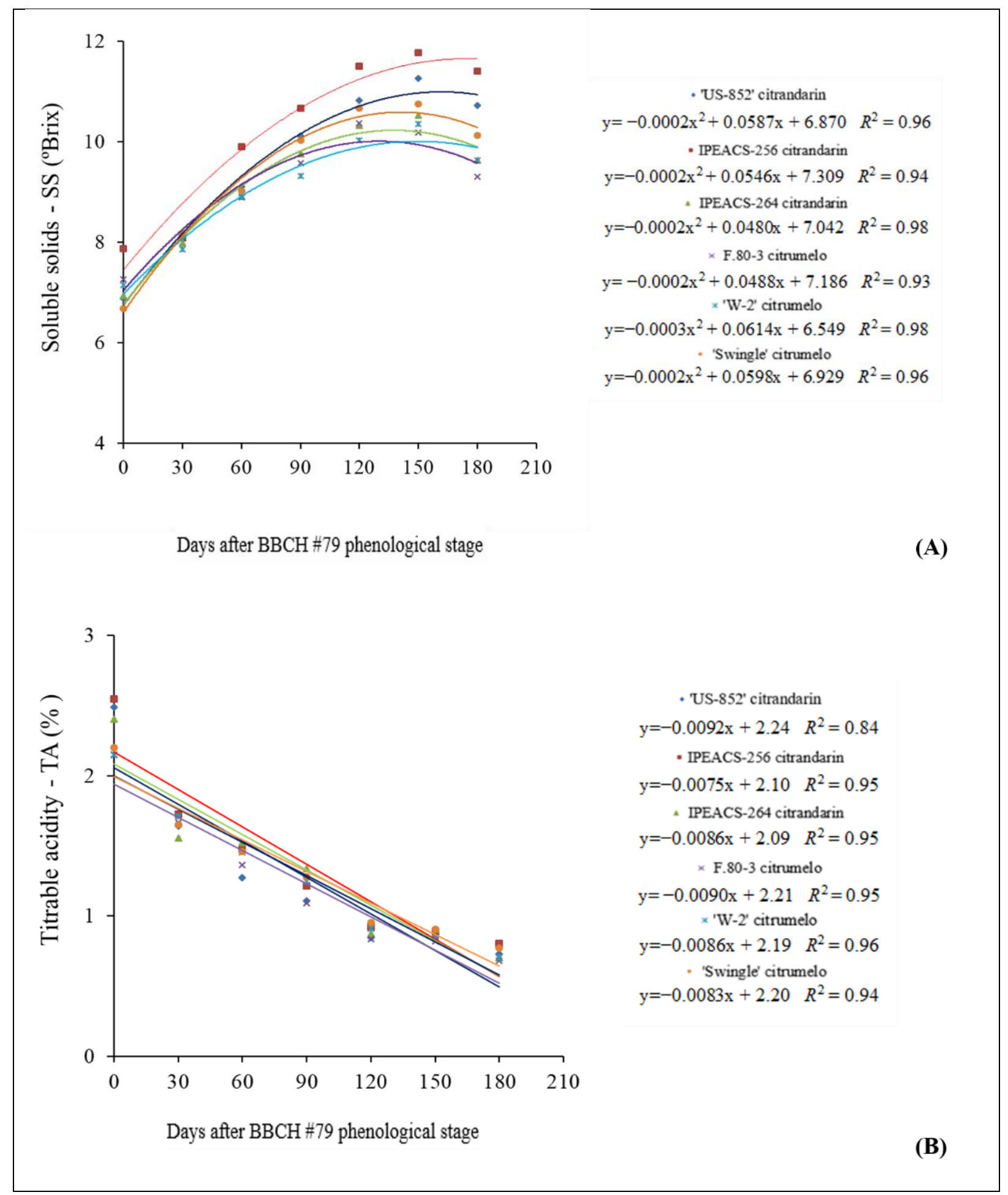

Figure 4. Development of 'Valencia' orange fruit ripening when trees are grafted on different 'Trifoliata' hybrid rootstocks at São Sebastião da Amoreira. (A): soluble solids (SS as ${ }^{\circ}$ Brix); (B): titratable acidity (TA as \%). Phenological stage BBCH \#79 (Meier, 2001), approximately to 200 days after flowering. 


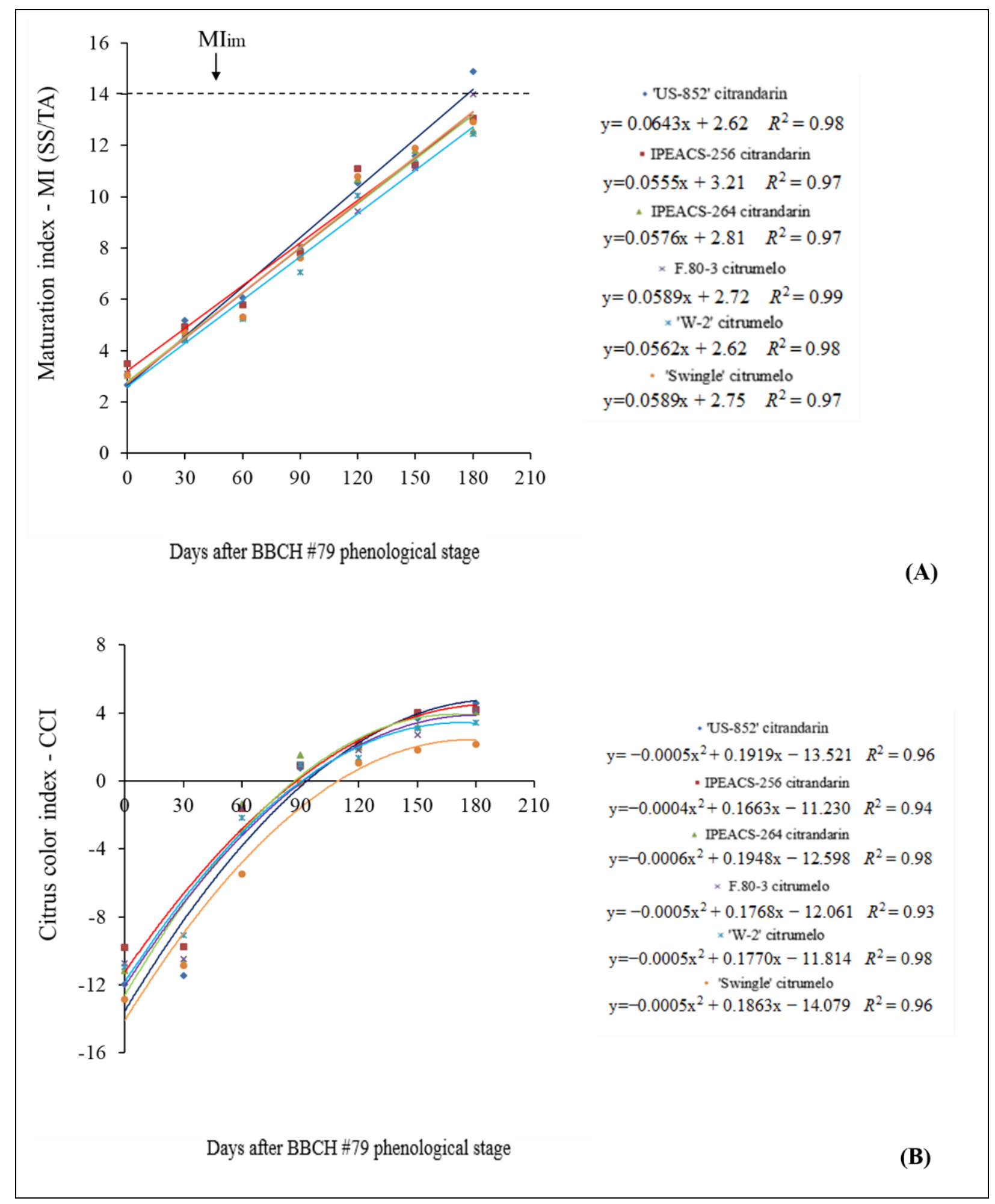

Figure 5. Development of 'Valencia' orange fruit ripening when trees are grafted on different 'Trifoliata' hybrid rootstocks at São Sebastião da Amoreira. (A): maturation index (MI) or ratio (SS/TA); (B): citrus color index (CCI). $\mathrm{MI}_{\mathrm{im}}=\mathrm{ideal}$ mean maturation index = 14. Phenological stage BBCH \#79 (Meier, 2001), approximately to 200 days after flowering. 


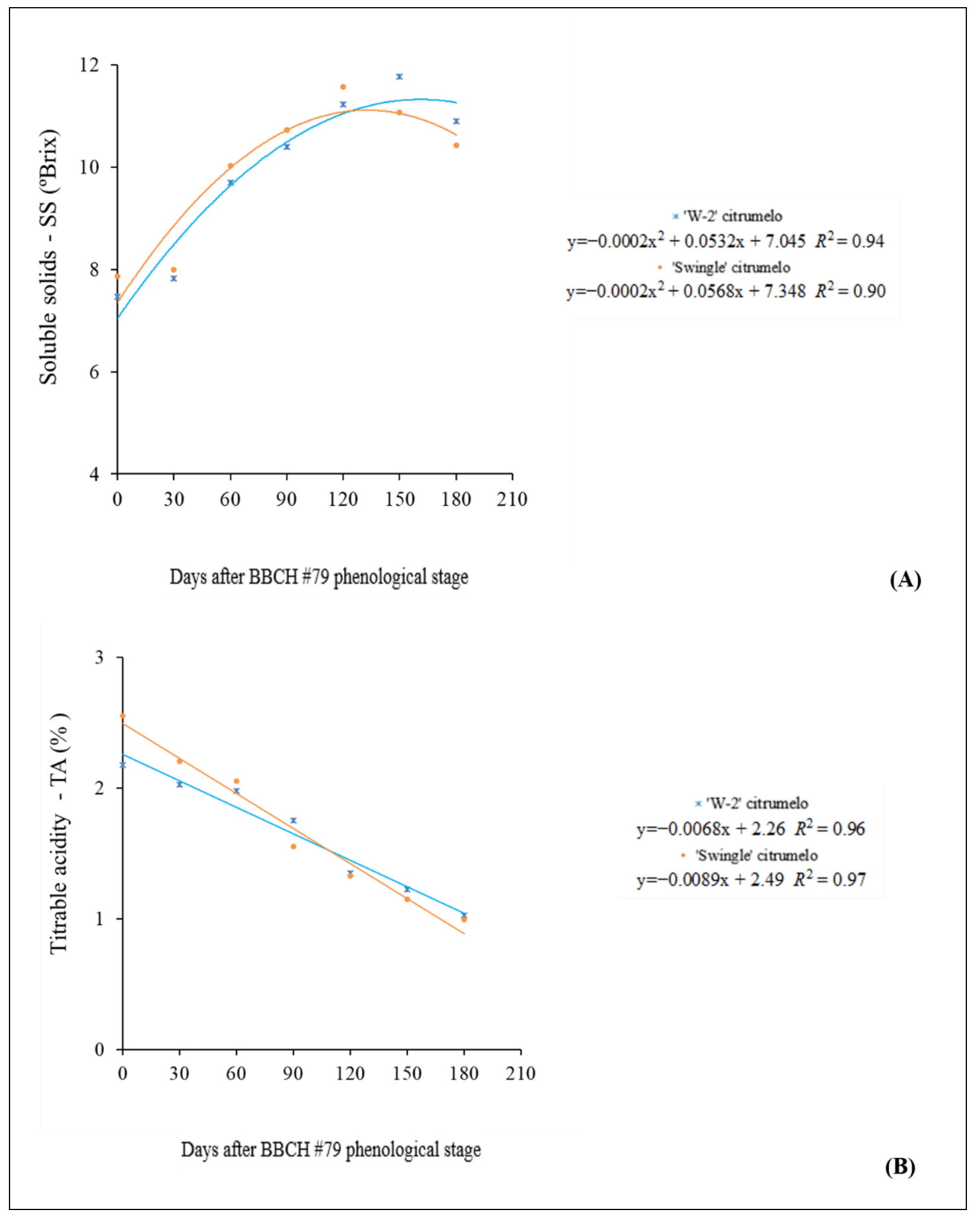

Figure 6. Development of 'Valencia' orange fruit ripening when trees are grafted on different 'Trifoliata' hybrid rootstocks at São Jerônimo da Serra. (A): soluble solids (SS as ${ }^{\circ}$ Brix); (B): titratable acidity (TA as \%). Phenological stage BBCH \#79 (Meier, 2001), approximately to 200 days after flowering. 


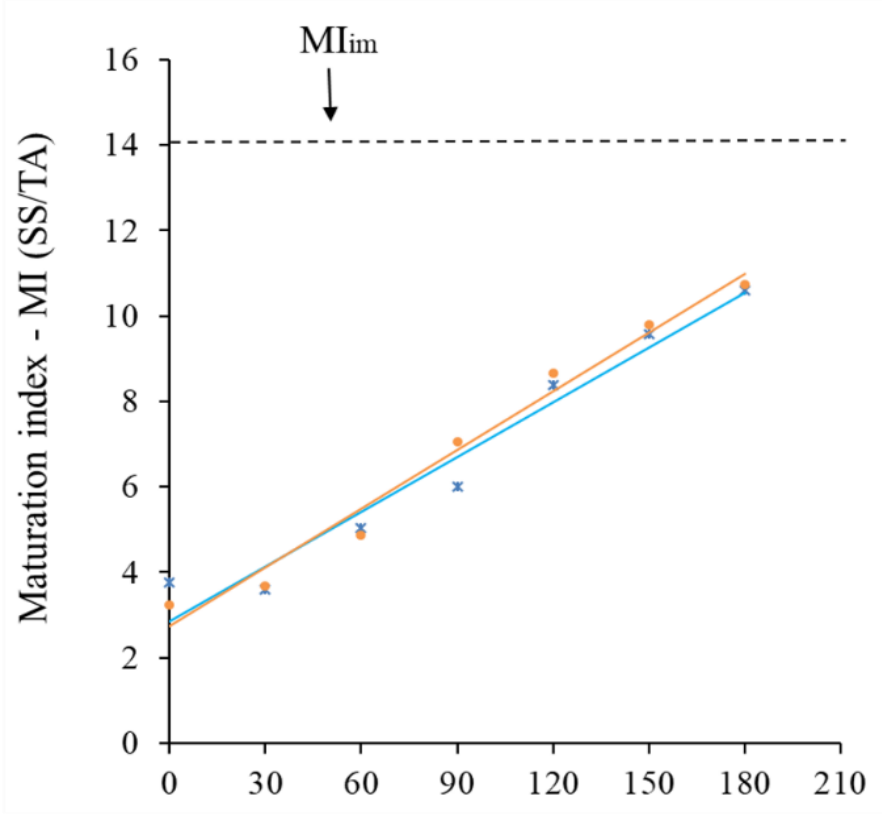

$\times$ 'W-2' citrumelo $\mathrm{y}=0.0427 \mathrm{x}+2.86 R^{2}=0.96$

- 'Swingle' citrumelo $\mathrm{y}=0.0458 \mathrm{x}+2.74 R^{2}=0.98$

Days after $\mathrm{BBCH} \# 79$ phenological stage

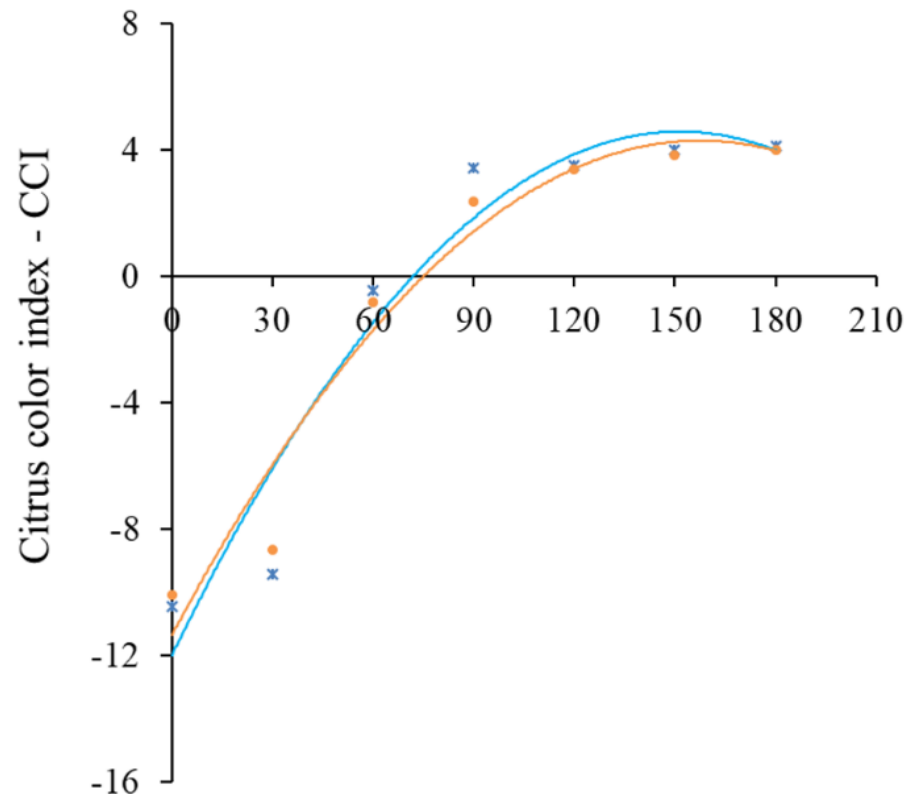

Days after $\mathrm{BBCH} \# 79$ phenological stage

Figure 7. Development of 'Valencia' orange fruit ripening when trees are grafted on different 'Trifoliata' hybrid rootstocks at São Jerônimo da Serra. (A): maturation index (MI) or ratio (SS/TA); (B): citrus color index (CCI). $\mathrm{MI}_{\mathrm{im}}=\mathrm{ideal}$ mean maturation index = 14. Phenological stage BBCH \#79 (Meier, 2001), approximately to 200 days after flowering.

Maximum and minimum temperatures differ even within a small interval between the latitudes of orange-producing areas, which may cause changes in fruit maturation and harvest dates as well as the behavior of scion varieties over each rootstock. Therefore, the ripening behavior found for 'Valencia' orange on 'Trifoliata' hybrid rootstocks in different 
subtropical growing scenarios is an important source of information for planning the marketing of fresh fruits or the industrial processing of fruits. In other words, the optimum date for harvesting can be estimated, helping to select the most appropriate rootstock genotypes according to production and processing from a commercial point of view.

The fruits of 'Valencia' orange trees grafted on 'Trifoliata' hybrid rootstocks grown at the RA location, with hot summers and low thermal amplitude during the ripening period, exhibited certain difficulty in terms of skin color change, remaining a shade of green for a long time, requiring an extended period from the beginning of the evaluations to reach CCI $=0$, from 107 to 141 days (Figure 2B). When grown at the SSA and SJS locations, this period ranged from 93 to 105 days (Figure 3B) and from 64 to 69 days (Figure 3B), respectively.

The change in fruit skin color occurs due to the degradation of chlorophyll, which is responsible for the green color of fruits, and an increase in carotenoid pigments, which gives the fruit intense yellow and orange hues [50,51]. Color breaks in subtropical areas generally occur in mid-autumn when temperatures decrease, and day length diminishes. The decline in rind chlorophyll proceeds over several months, and the onset of carotenoid accumulation almost coincides with the disappearance of chlorophyll [46].

Air temperature has the greatest influence on the external color of oranges throughout maturation. Usually, the skin color of fruits grown in colder regions changes earlier. In contrast, with fruits grown in warm regions, changes occur later, and in some cases, the external color of the fruits may not develop satisfactorily [51-53]. Moreover, the genetic differences in rootstocks and their relationships with different scion varieties may influence the CCI [54-56], and it was shown in this work that citrandarins, in general, had higher CCI values than citrumelos.

Color is considered one of the most important external factors for the quality of orange fruits, as they are mainly marketed as fresh fruits, and the visual aspect of the product is considered an index of quality and maturation. However, skin maturation or morphological maturation does not always coincide with juice maturation in oranges grown in warmer tropical regions [7,12]. In addition, citrus is harvested based on internal quality (edibility), and skin changes have not been related to the best harvest times [57]. Although the 'Valencia' oranges grown at the SJS location underwent rapid development of $\mathrm{CCI}$, it took a long time to reach the $\mathrm{MI}_{\mathrm{im}}$, confirming that $\mathrm{CCI}$ should not be used as a ripening reference alone for juice processing when growing this variety in regions with temperate summers and at high elevations. The fruits grown at the RA location, correspondingly, took less time to reach the $\mathrm{MI}_{\mathrm{im}}$, but reaching a $\mathrm{CCI}=0$ of the skin took a long time; thus, if the aim is to market fruit with a more attractive appearance, then it is necessary to extend the timing of harvest until they reach the desired skin color.

The 'Valencia' orange fruits grafted on 'US-852' or IPEACS-256 citrandarins grown in locations with hot summers presented an earliness characteristic, they reached the $\mathrm{MI}_{\mathrm{im}}$ over a short period when compared with the other rootstocks evaluated. These genotypes are, therefore, a robust option for anticipating fruit harvest in order for citrus processing plants to operate earlier, over a wider period of the year.

In general, the basic quality of orange juice is determined by the fruit processor, that is, by the quality of fruit juice accepted at the reception area. Subsequent processing steps cannot improve the main quality parameters of a given production batch, except by blending a particular juice with superior quality orange juice or concentrate. In extracted juice, the concentration of sugar typically varies from $9{ }^{\circ}$ Brix for early season varieties to $12{ }^{\circ}$ Brix for fruit harvested late in the season. However, citrus processors usually consider $11.8^{\circ}$ Brix and $11.0^{\circ}$ Brix as the minimum grade of orange juice for FCOJ and NFC, respectively, or an MI ranging from 12.5 to 20.5 for both [42,58]. MI offers a more comprehensive analysis of orange juice quality because it also considers its organic acid content. Nevertheless, the removal of acid from the juice, also known as deacidification, would also increase MI but is not permitted for orange juice in most countries [42,59]. Thus, the SS content in fact had a major impact on MI in these trials, as the 'Trifoliata' hybrid 
rootstocks had no influence on this juice characteristic (Tables 1, 3 and 5). This range of MI permits processors to market different kinds of juices according to their consumer preference, but off-specification oranges are rejected to ensure robust quality juices. Thus, the monitoring of orange ripening when trees are grafted on different rootstocks at a given location is essential to improve juice quality.

Although earliness is a characteristic of the scion, the rootstock may change the ripening development of orange fruits $[30,33,35]$; thus, rootstock selection plays a crucial role in new citrus orchards. The rootstock is an important component of a healthy and productive citrus tree, influencing the fruit yield, fruit quality, tree size, and tolerance of diseases [60,61]. However, the selection of rootstocks in many growing countries has been based mainly on disease control.

Currently, in Sao Paulo State, Brazil, 'Rangpur' lime and 'Swingle' citrumelo are the main rootstocks, while in Florida, US, 'Carrizo' citrange and 'Swingle' citrumelo are the main rootstocks $[62,63]$. As demonstrated in this work, some citrandarin rootstocks, such as 'US-852' and IPEACS-256, are strong options for improving the quality of orange juice, and diversification is an important tool to avoid emerging and destructive diseases that put the citrus industry at risk.

The results of this study provide new information in terms of rootstock selection for 'Valencia' orange trees, taking into consideration the location, climatic conditions, and demands of each market, using certain important characteristics of orange fruit ripening development, such as the $\mathrm{MI}_{\mathrm{im}}$ and CCI.

\section{Conclusions}

The aim of this work was to assess the ripening development of 'Valencia' orange fruits when trees are grafted on different 'Trifoliata' hybrid rootstocks, grown in different subtropical locations, to obtain high-quality fruits. In general, the rootstocks influenced the main features of orange ripening, such as soluble solids content, maturation index, and citrus color index. At the RA location (380 m a.s.l), trees on IPEACS-256 and 'US-852' citrandarins had the highest SS and the 'US-852' citrandarin the highest MI, reaching the $\mathrm{MI}_{\mathrm{im}}$ earlier than the other rootstocks. The highest $\mathrm{CCI}$ was achieved when trees were on IPEACS-256 citrandarin. At the SSA location (650 m a.s.l.), trees on 'US-852', IPEACS-256, and IPEACS-264 citrandarins had the highest SS, but on 'US-852' had the highest MI, reaching the earliest $\mathrm{MI}_{\mathrm{im}}$ among the rootstocks. The highest $\mathrm{CCI}$ was achieved when trees were on'US-852' and IPEACS-256 citrandarins. At the SSJ location (835 $\mathrm{m}$ a.s.l.), there was no significant effect of rootstocks on 'Valencia' orange fruits for any of the variables evaluated. This assessment can be useful in the planning of new orchards producing high-quality fruits with desirable features for the orange juice industry.

Author Contributions: E.F.C., A.R.D., C.D.M.M. and S.R.R. conceived and designed the experiments. A.R.D., E.F.C., C.D.M.M. and C.H.d.S.G. performed the experiments. A.R.D. and L.S.A.G. analyzed the data, A.R.D., S.R.R. and E.F.C. wrote the manuscript. All authors have read and agreed to the published version of the manuscript.

Funding: This work was partially supported by the Brazilian Federal Agency for Support and Evaluation of Graduate Education (CAPES) within the Ministry of Education, Finance Code 001.

Conflicts of Interest: The authors declare no conflict of interest.

\section{References}

1. Saunt, J. Citrus varieties of the world. In An Illustrated Guide, 1st ed.; Sinclair International Limited: Norwich, UK, $2000 ;$ p. 160.

2. Spreen, T.H. The word citrus industry. In Soils, Plant Growth and Crop Production, 1st ed.; Verheye, W.H., Ed.; UNESCO/Eolss Publishers: Singapore, 2010; pp. 249-269.

3. Bastos, D.C.; Ferreira, E.A.; Passos, O.S.; de Sá, J.F.; Ataíde, E.M.; Calgaro, M. Cultivares copa e porta-enxertos para a citricultura brasileira. Inf. Agropec. 2014, 35, 36-45.

4. Carvalho, S.A.; Girardi, E.A.; Mourão Filho, F.A.A.; Ferrarezi, R.S.; Filho, H.D.C. Advances in citrus propagation in Brazil. Rev. Bras. Frutic. 2019, 41, e-422. [CrossRef] 
5. USDA United States Department of Agriculture. Citrus: Markets and Trade. Foreign Agricultural Service. 2019. Available online: https:/ /apps.fas.usda.gov/psdonline/circulars/citrus.pdf (accessed on 15 June 2019).

6. Bermejo, A.; Cano, A. Analysis of nutritional constituents in twenty citrus cultivars from the Mediterranean area at different stages of ripening. Food. Nutr. Sci. 2012, 3, 639-650. [CrossRef]

7. Lado, J.; Zacarías, L.; Rodrigo, M.J. Maturity indicators and citrus quality. Stewart Postharvest Rev. 2014, 10, 1-6.

8. Davies, F.S.; Albrigo, L.G. Environmental factors affecting fruit growth, development and quality. In Citrus, 2nd ed.; Davies, F.S., Albrigo, L.G., Eds.; Cab International: Wallingford, SC, USA, 1994; pp. 77-82.

9. Ladaniya, M.S. Citrus Fruit: Biology, Technology and Evaluation, 2nd ed.; Elsevier Inc.: Amsterdam, The Netherlands, 2008 ; p. 593.

10. Sato, A.J.S.; Silva, B.S.J.; Bertolucci, R.; Carielo, M.; Guiraud, M.C.; Fonseca, I.C.B.; Roberto, S.R. Ripening evolution and physico-chemical characteristics of 'Isabel' grape on different rootstocks in North of Parana. Semin. Agrar. 2009, 30, 11-20. [CrossRef]

11. Itakura, K.; Saito, Y.; Suzuki, T.; Kondo, N.; Hosoi, F. Estimation of citrus maturity with fluorescence spectroscopy using deep learning. Horticulturae 2019, 5, 2. [CrossRef]

12. El-Otmani, M.; Ait-Oubahou, A.; Zacarias, L. Citrus spp.: Orange, mandarin, mandarin, clementine, grapefruit, pomelo, lemon and lime. In Postharvest Physiology and Technology: Tropical and Subtropical Fruits, 1st ed.; Yahia, E.M., Ed.; Woodhead publishing: Cambridge, UK, 2011; pp. 437-516.

13. Tietel, Z.; Srivastava, S.; Fait, A.; Tel-Zur, N.; Carmi, N.; Raveh, E. Impact of scion/rootstock reciprocal effects on metabolomics of fruit juice and phloem sap in grafted Citrus reticulata. PLoS ONE 2020, 15, e0227192. [CrossRef]

14. Hanana, M.; Hamrouni, L.; Hamed, K.; Abdelly, C. Influence of the rootstock/scion combination on the grapevines behavior under salt stress. J. Plant Biochem. Physiol. 2015, 3. [CrossRef]

15. Naor, A.; Klein, I.; Doron, I. Stem water potential and apple size. J. Am. Soc. Hortic. Sci. 1995, 120, 577-582. [CrossRef]

16. Shackel, K.A.; Ahmadi, H.; Biasi, W.; Buchner, R.; Goldhamer, D. Plant water status as an index of irrigation need in deciduous fruit trees. Horttechnology 1997, 7, 23-29. [CrossRef]

17. Stenzel, N.M.C.; Neves, C.S.V.J.; Marur, C.J.; Scholz, M.B.S.; Gomes, J.C. Maturation curves and degree-days accumulation for fruits of 'Folha Murcha' orange trees. Sci. Agric. 2006, 63, 219-225. [CrossRef]

18. Pompeu, J., Jr. Porta-enxertos. In Citros; Mattos, D., Jr., Ed.; Instituto Agronômico/Fundag: Campinas, Brazil, 2005 ; pp. 63-104.

19. Castle, W.S. A career perspective on citrus rootstocks, their development, and commercialization. Hortscience 2010, 45, 11-15. [CrossRef]

20. Castle, W.S.; Baldwin, J.C. Rootstock effects on 'Hamlin' and 'Valencia' orange trees growing at central ridge and flatwoods locations. Hortscience 2005, 118, 4-14.

21. Pompeu, J., Jr.; Blumer, S. Citrumelos como porta-enxertos para laranja 'Valência'. Pesq. Agropec. Bras. 2011, 46, 105-107. [CrossRef]

22. Pompeu, J., Jr.; Blumer, S. Hibridos de trifoliata como porta-enxertos para laranjeira Pêra. Pesq. Agropec. Trop. 2014, 44, 9-14. [CrossRef]

23. Bowman, K.D.; McCollum, G.; Albrecht, U. Performance of 'Valencia' orange [Citrus sinensis (L.) Osbeck] on 17 rootstocks in a trial severely affected by huanglongbing. Sci. Hortic. 2016, 201, 355-361. [CrossRef]

24. Hutchison, D.J. Swingle citrumelo-a promising rootstock hybrid. Proc. Fla. State Hort. Soc. 1974, 87, 89-91.

25. Wutscher, H.K.; Hill, L.L. Performance of 'Hamlin' orange on 16 rootstocks in East-Central Florida. Hortscience 1995, 30, 41-43. [CrossRef]

26. Bowman, K.D.; Wutscher, H.K.; Kaplan, D.T.; Chaparro, J.X. A new hybrid citrus rootstock for Florida: US-852. Proc. Fla. State Hortic. Soc. 1999, 112, 54-55.

27. Castle, W.S.; Baldwin, J.C.; Grosser, J.W. Performance of 'Washington' navel orange trees in rootstocks trials located in Lake and St. Lucie counties. Proc. Fla. State Hortic. Soc. 2000, 113, 106-111.

28. Schinor, E.H.; Cristofani-Yaly, M.; Bastianel, M.; Machado, M.A. Sunki Mandarin vs Poncirus trifoliata hybrids as rootstocks for Pera sweet orange. J. Agric. Sci. 2013, 5, 190-200. [CrossRef]

29. França, N.O.; Amorim, M.S.; Girardi, E.A.; Passos, O.S.; Soares Filho, W.S. Performance of 'Tuxpan Valencia' sweet orange grafted onto 14 rootstocks in northern Bahia, Brazil. Rev. Bras. Frutic. 2016, 38, e-684. [CrossRef]

30. Castle, W.S.; Baldwin, J.C.; Murano, R.P. Performance of 'Valencia' sweet orange trees on 12 rootstocks at two locations and an economic interpretation as a basis for rootstock selection. Hortscience 2010, 45, 523-533. [CrossRef]

31. Castle, W.S.; Baldwin, J.C.; Murano, R.P. Rootstocks and the performance and economic returns of 'Hamlin' sweet orange trees. Hortscience 2010, 45, 875-881. [CrossRef]

32. Cantuarias-Avilés, T.; Mourão Filho, F.A.A.; Stuchi, E.S.; Silva, S.R.; Espinoza-Nuñez, E. Horticultural performance of 'Folha Murcha' sweet orange onto twelve rootstocks. Sci. Hortic. 2011, 129, 259-265. [CrossRef]

33. Donadio, L.C.; Lederman, I.E.; Roberto, S.R.; Stuchi, E.S. Dwarfing-canopy and rootstock cultivars for fruit trees. Rev. Bras. Frutic. 2019, 41, e997. [CrossRef]

34. Cavalcante, I.H.L.; Martins, A.B.G.; Stuchi, E.S.; Campos, M.C.C. Fruit Maturation as a parameter for selection of sweet orange cultivars in Brazil. J. Food Agric. Environ. 2009, 7, 316-319.

35. Carlos, E.F.; Stuchi, E.S.; Donadio, L.C. Porta-Enxertos Para a Citricultura Paulista; Funep: Jaboticabal, Brazil, 1997; 47p.

36. Alvares, C.A.; Stape, J.S.; Gonçalves, J.L.M.; Sparovek, G. Köppen's climate classification map for Brazil. Meteorol. Zeitschrift 2013, 22, 711-728. [CrossRef]

37. Nietsche, P.R.; Caramori, P.H.; da Ricce, W.S.; Pinto, L.F.D. Atlas Climático do Estado do Paraná; PR, IAPAR: Londrina, Brazil, 2019.

38. Rodrigues, M.J.S.; Ledo, C.A.S.; Girardi, E.A.; Almeida, L.A.H.; Soares Filho, W.S. Caracterização de frutos e propagação de porta-enxertos híbridos de citros em ambiente protegido. Rev. Bras. Frutic. 2015, 37, 457-470. [CrossRef]

39. Castle, W.S.; Wutscher, H.K.; Youtsey, C. Citrumelos as rootstocks for Florida citrus. Proc. Fla. State Hortic. Soc. 1988, 101, $28-33$. 
40. Meier, U. Growth Stages of Mono and Dicotyledonous Plants: BBCH Monograph, 2nd ed.; Federal Biological Research Centre for Agriculture and Forestry, Blackwell: Oxford, UK, 2001; p. 158.

41. AOAC. Association of Official Analytical Chemists. In Official Methods of Analysis, 15th ed.; AOAC: Arlington, VA, USA, 1990; 298p.

42. Ringblom, U. The Orange Book, 3rd ed.; Tetra Pak Processing Systems AB: Lund, Sweden, 2017; 208p.

43. Jimenez-Cuesta, M.; Cuquerella Cayuela, J.; Martinez-Javega, J.M. Teoria y Practicca de la Desverdización de Los Cítricos; INIA: Madrid, Spain, 1983; 22p.

44. Ferreira, D.F. Sisvar: A computer statistical analysis system. Ciência Agrotecnologia (UFLA) Lavras 2011, 35, 1039-1042. [CrossRef]

45. R Core Team. R: A Language and Environment for Statistical Computing; R Foundation for Statistical Computing: Vienna, Austria, 2017; Available online: http:/ / www.R-project.org/ (accessed on 17 August 2020).

46. Iglesias, D.J.; Cercós, M.; Colmenero-Flores, J.M.; Naranjo, M.A.; Ríos, G.; Carrera, E.; Ruiz-Rivero, O.; Lliso, I.; Morillon, R.; Tadeo, F.R.; et al. Physiology of citrus fruiting. Braz. J. Plant Physiol. 2007, 19, 333-362. [CrossRef]

47. Perez-Perez, J.G.; Robles, J.M.; Botia, P. Influence of deficit irrigation in phase 3 of fruit growth on fruit quality in 'Lane late' sweet orange. Agric. Water Manag. 2009, 96, 969-974. [CrossRef]

48. Kallsen, C.E.; Sanden, B. Early navel orange fruit yield, quality, and maturity in response to late-season water stress. Hortscience 2011, 46, 1163-1169. [CrossRef]

49. Susanto, S.; Abdila, A.; Sulistyningrum, D. Growth and postharvest quality of mandarin (Citrus reticulata 'Fremont') fruit harvested from different altitudes. Acta. Hortic. 2013, 975, 421-426. [CrossRef]

50. Lee, H.S.; Castle, W.S. Seasonal changes of carotenoid pigments and colour in Hamlin, Earlygold, and Budd Blood orange juices. J. Agric. Food Chem. 2001, 49, 877-882. [CrossRef]

51. Rodrigo, M.J.; Alquezar, B.; Alos, E.; Lado, J.; Zacarias, L. Biochemical bases and molecular regulation of pigmentation in the skin of citrus fruit. Sci. Hortic. 2013, 163, 42-62. [CrossRef]

52. Mesejo, C.; Gambetta, G.; Gravina, A.; Martinez-Fuentes, A.; Reig, C.; Agusti, M. Relationship between soil temperature and fruit color development of 'Clemenpons' Clementine mandarin (Citrus clementina Hort. ex. Tan). J. Sci. Food Agric. 2012, 92, 520-525. [CrossRef]

53. Porras, I.; Brotons, J.M.; Conesa, A.; Manera, F.J. Influence of temperature and net radiation on the natural degreening process of grapefruit (Citrus paradisi Macf.) cultivars 'Rio Red' and 'Star Ruby'. Sci. Hortic. 2014, 173, 45-53. [CrossRef]

54. Legua, P.; Forner, J.B.; Hernandez, F.; Forner-Giner, M.A. Physicochemical properties of orange juice from ten rootstocks using multivariate analysis. Sci. Hortic. 2013, 160, 268-273. [CrossRef]

55. Forner-Giner, M.A.; Rodriguez-Gamir, J.; Martinez-Alcantara, B.; Quinones, A.; Iglesias, D.J.; Primo-Millo, E.; Forner, J. Performance of 'Navel' orange trees grafted onto two new dwarfing rootstocks (Forner-Alcaide 517 and Forner-Alcaide 418). Sci. Hortic. 2014, 179, 376-387. [CrossRef]

56. Continella, A.; Panniteri, C.; La Malfa, S.; Legua, P.; Distefano, G.; Nicolosi, E.; Gentile, A. Influence of different rootstocks on yield precocity and fruit quality of 'Tarocco Scirè' pigmented sweet orange. Sci. Hortic. 2018, 230, 62-67. [CrossRef]

57. Alam-Eldein, S.; Albrigo, G.; Etxeberria, E.; Burns, J.; Rouseff, R.; Tubeileh, A. Characterization of 'Valencia' orange skin maturation: Effect of water stress and growth regulators. Acta Hortic. 2017, 1150, 355-362. [CrossRef]

58. Cinquanta, L.; Di Matteo, M. The Quality of Orange Juice. In Diet Quality Nutrition and Health; Preedy, V., Hunter, L.A., Patel, V., Eds.; Humana Press: New York, NY, USA, 2013. [CrossRef]

59. Goboulev, V.N.; Salem, B. Traitement a'l'électrodialyse du jus d'orange. Ind. Aliment. Agric. 1989, 106, $175-177$.

60. Barry, G.H.; Castle, W.S.; Davies, F.S. Soluble Solids Accumulation in 'Valencia' Sweet Orange as Related to Rootstock Selection and Fruit Size. J. Amer. Soc. Hortic. Sci. 2004, 129, 594-598. [CrossRef]

61. Bisi, R.B.; Albrecht, U.; Bowman, K.D. Seed and Seedling Nursery Characteristics for 10 USDA Citrus Rootstocks. Hortscience 2020, 55, 528-532. [CrossRef]

62. Carvalho, H.W.L.; Teodoro, A.V.; Barros, I.; Carvalho, L.M.; Soares Filho, W.S.; Girardi, E.A.; Passos, O.S.; Pinto-Zevallos, D.M. Rootstock-related improved performance of 'Pera' sweet orange under rainfed conditions of Northeast Brazil. Sci. Hortic. 2020, 263, 109-148. [CrossRef]

63. Bowman, K.D.; Joubert, J. Citrus rootstocks. In The Genus Citrus; Talon, M., Caruso, M., Gmitter, F.G., Eds.; Woodhead Publishing: Cambridge, UK, 2020; pp. 105-127. [CrossRef] 